Article

\title{
Value Relevance of Corporate Environmental Performance: A Comprehensive Analysis of Performance Indicators Using Korean Data
}

\author{
Hyunwoo Choi ${ }^{1}$, Ingoo Han ${ }^{2}$ (D) and Jaywon Lee ${ }^{3, *}$ \\ 1 Agenda Research, NAVER, Seongnam 13561, Korea; hyunwoo.choi0@gmail.com \\ 2 College of Business, Korea Advanced Institute of Science and Technology (KAIST), Seoul 02455, Korea; \\ ighan@kaist.ac.kr \\ 3 College of Business Administration, Sejong University, Seoul 05006, Korea \\ * Correspondence: jaywonlee@sejong.ac.kr; Tel.: +82-2-3408-3179
}

Received: 24 July 2020; Accepted: 1 September 2020; Published: 3 September 2020

\begin{abstract}
This paper examines the value relevance of corporate environmental performance (CEP) using individual environmental performance indicators and multidimensional constructs derived from Trumpp et al. (2015). Accounting information can be described as 'value-relevant' when the information in financial statements has the ability to explain firm value. In recent years, stakeholders such as governments, public institutions, firms, customers, and local communities have recognized the importance of corporate environmental performance. Thus, one of the main research questions is whether corporate environmental performance is value relevant. The empirical results in this paper indicate that only a few individual environmental performance indicator variables are value relevant, while most environmental performance constructs have a significant impact on firm value. Our findings suggest that firm value significantly increases with improved environmental management or operational performance. In addition, environmental performance indicators and environmental performance constructs have a significant impact on firms in environmentally sensitive industries, confirming the notion of higher value relevance of environmental information for firms in these industries. This study contributes to prior literature by carrying out a comprehensive analysis on the multidimensional nature of corporate environmental performance and its impact on value relevance. This paper also reconciles extant literature on the construct validity of environmental performance indicators and environmental performance constructs by formulating standardized composite measures of CEP following Larker et al. (2007).
\end{abstract}

Keywords: corporate environmental performance; multidimensionality; value relevance; ohlson model

\section{Introduction}

In Korea, the publication of sustainability reports has increased steadily in recent years as stakeholders such as governments and public institutions, firms, customers, and individuals in local communities recognize the importance of corporate environmental performance (hereafter CEP). Many prior studies examine the relationship between CEP and corporate financial performance (e.g., [1-4]). The main question in the literature has been whether it is worthwhile to "pay to be green". Accounting information can be described as 'value-relevant' when the information in financial statements has the ability to explain firm value. In accounting research, scholars with considerable interest in CEP examine whether capital markets utilize environmental information in the process of firm valuation [2-4]. They empirically investigate whether environmental information can provide additional explanatory power, adding the value relevance of accounting information. These studies 
examine the value relevance of CEP using various measures, including Superfund-related liabilities, sulfur dioxide $\left(\mathrm{SO}_{2}\right)$ emissions, and carbon emissions [2,4,5]. Since each research has its own proxy for environmental performance, McWilliams and Sigel [6] warn that the empirical findings in prior studies cannot be reliably compared. For this reason, it is necessary to establish an explicit and comprehensible definition of CEP and clear indicators for common use in research $[7,8]$.

Rahman and Post [9] address the issue of measuring environmental corporate social responsibility constructs and the need to develop a more consistent and transparent measure. However, CEP may be difficult to represent conceptually. Xie and Hayase [8] propose a two-dimensional CEP measurement model, composed of environmental management performance (EMP) and environmental operational performance (EOP). However, from a methodological viewpoint, the construct validity of these measures is not guaranteed since they use the principal component analysis method [10]. Trumpp et al. [11] extend the work of Xie and Hayase [8] and validate the constructs related to CEP measurement more comprehensively. By applying a two-stage procedure composed of an exploratory factor analysis (EFA) and a confirmatory factor analysis (CFA), they identify a multidimensional EPC consisting of one EMP dimension and two EOP dimensions.

Based on the Ohlson model [12], this paper studies the value relevance of CEP, including individual environmental performance indicators (EPI) as well as multidimensional environmental performance constructs (EPC) derived from Trumpp et al. [11]. Using observations of 218 Korean firms for which both financial and environmental performance data were available for the years 2009 to 2013, we find that some EPIs show additional value relevance compared to the traditional Ohlson model, while others do not. These results have economic significance in that firm value increases significantly with improved environmental management and/or operational performance. For instance, firm value is on average KRW 2.101 billion higher for firms with an energy efficiency policy. In addition, we find that some EPCs have a significant and positive impact on firm market value. However, some EPIs fail to add value relevance due to the multicollinearity problem. Interestingly, the multicollinearity problem is not evident in regression models that adopt EPCs instead of EPI variables. We also find that EPI variables and EPCs are significant only among firms in environmentally sensitive industries, indicating a higher value relevance of environmental information for firms in such industries but not in others.

This study contributes to the extant literature in three ways. First, it adds empirical evidence on the value relevance of CEP. This study focuses on Korea, where the publication of environmental reporting has increased steadily in recent years as stakeholders, such as the government, customers, and individuals in local communities, increasingly recognize the importance of CSR activities. Second, by contrasting the results of our empirical analysis of EPIs and EPCs that have construct validity, we highlight the methodological problems inherent in prior studies. Examples of these include the study of $\mathrm{SO}_{2}$ emissions by Hughes [5], and the study of carbon emissions by Matsumura et al. [4]. Third, we provide empirical evidence of the value relevance of CEP by adopting a comprehensive methodological approach by constructing composite measures. We show additional evidence that supports that the multidimensional nature of CEP should be considered in corporate decision-making [11,13].

This study is structured as follows: Section 2 reviews prior literature addressing the value relevance of firms' environmental performance and its various dimensions. The hypotheses are developed in the subsequent section. We then describe the research models and methodologies in Section 4. In Section 5 , we present the results of the regression analyses, and Section 6 concludes. Abbreviations part provides definitions of abbreviations in this study.

\section{Literature Review}

\subsection{Value Relevance of Firms' Environmental Performance}

Prior studies examine the value relevance of environmental performance of firms using a number of proxies such as Superfund-related liabilities, sulfur dioxide $\left(\mathrm{SO}_{2}\right)$ emissions, Toxic Release Inventory (TRI) emissions, and carbon emissions [2,4,5,14]. 
Barth and McNichols [2] examine whether Superfund-related liabilities are incrementally relevant for firms' market value. Superfund sites are those with hazard scores exceeding 28.5 as determined by the Environmental Protection Agency (EPA), based on evaluation of various conditions, such as proximity to the population and drinking water. Sites with these scores have been identified by the EPA as containing hazardous waste that constitutes a potential threat to public health and safety. The EPA conducts investigations to identify parties potentially responsible for contamination at such sites; these parties are requested to pay for a remedial investigation and feasibility study, which can cost millions of dollars. The EPA then files a record of decision, which summarizes the findings and recommendations of the study and includes estimates of the cleanup costs. The valuation of the EPA indicates that remediation of Superfund sites provides additional value relevance to recognized assets and liabilities and increases firm market value.

Clarkson et al. [15] examine market evaluations of firms' environmental capital expenditures in the US pulp and paper industry, in line with Barth and McNichols [2]. Investors utilize environmental capital expenditures as proxies for unbooked environmental liabilities only for firms with poor environmental performance. Cormier and Magnan [3] claim that investors consider unbooked environmental liabilities among Canadian companies. Hart and Ahuja [16] empirically examine the relation between emissions reduction and firm performance. They utilize the Investor Responsibility Research Center (IRRC) database to infer the environmental variables. Using the S\&P 500 sample, they find that efforts to reduce emissions through pollution prevention increase firm performance (e.g., ROS, ROA) significantly.

Some studies examine $\mathrm{SO}_{2}$ emissions trading schemes (ETS) in the U.S. and the market-value relevance of excess emission allowances [5,17]. Hughes [5] examines the value relevance $\mathrm{of}_{2}$ emissions for firms in the electric utilities industry. He shows that $\mathrm{SO}_{2}$ emissions are value-relevant, as the market reflected the cost of compliance with the Clean Air Act Amendment in the share price. Johnston et al. [17] extend the findings of prior literature by showing that the $\mathrm{SO}_{2}$ emission allowances of firms in the U.S. electric utilities industry are positively priced in the capital market.

Other studies investigate the informational value of the Toxics Release Inventory (TRI) [14,18]. Konar and Cohen [18] document a negative abnormal return related to firms that reported TRI data with substantial media attention. Connors et al. [14] empirically find that market reactions vary by industry in regards to TRI emissions information. In the electric utility industry, investors reward emissions decreases, but do not penalize increases. In contrast, the chemical industry penalizes emission increases, but do not reward decreases.

Chapple et al. [19] examine whether the capital market is pricing the proposed Australian Emission Trading System (ETS). Using carbon emission data from 58 Australian firms, the authors theoretically calculate the market impact of a firm's carbon intensity profile. Matsumura et al. [5] examine the value relevance of carbon disclosures as well as that of carbon emissions. They gather voluntarily-disclosed carbon emissions data of S\&P 500 firms during the years 2006-2008 and find that firm value decreased as the amount of carbon emissions increased. In addition, they also find higher values for disclosing firms than for non-disclosing firms.

Using a unique environmental dataset including 29 countries, Jo et al. [20] find that a reduction in environmental costs enhances ROA within one or two years after initiation. They argue that reducing environmental costs has a beneficial effect on firm performance by enhancing return on assets. They also document that this effect is more pronounced among financial firms in highly-developed capital markets than for firms in less-developed capital markets. Additionally, Kim et al. [21] show that a firm's legal origin is one of the main determinants of CEP. They find that firms operating in countries operating under civil law exhibit significantly higher levels of CEP than those operating in common law countries. More recently, Miralles-Quirós et al. [22] document the differing value relevance of environmental, social, and governance performance of firms listed in Brazil. Jiang and Fu [23] argue that corporate environmental performance is affected by difference stakeholders from observations of Chinese pollution-intensive firms. Sutopo et al. [24] examine the winners of the Sustainability Reporting Award (SRA) and find that SRA increases financial statement value relevance. 


\subsection{Framework of $C E P$}

Empirical research related to CEP has used many relevant indicators to measure this construct properly. However, as Etzion [7] points out, many scholars have used their own definitions of CEP, which makes the comparison of empirical results among different studies difficult. Construct validity must therefore be ensured, and a consistent definition adopted in order for empirical analyses to obtain meaningful results [25]. (Content validity is "the degree to which a measure represents a particular domain of content", and construct validity refers to "the correspondence between a construct and a measure taken as evidence of the construct" [26].)

Correspondingly, the ISO 14031 addresses the issue of CEP measurement. It separates environmental performance indicators into two classes: EMP and EOP indicators. (The ISO 14031 relates to the design and use of environmental performance evaluation. It defines an environmental performance indicator as "indicators related to information regarding organizational environmental performance". In addition, management and operational performance indicators are defined as an "environmental performance indicator that provides information about the management activities to influence an organization's environmental performance" and an "environmental performance indicator that provides information about the environmental performance of an organization's operational process", respectively [27].) The definitions provided in the ISO 14031 imply that CEP measurements should be composed of both management and operational performance indicators. As a consequence, recent studies establish the CEP measurements as multidimensional constructs [11,28]. (Law et al. [29] define a multidimensional construct as a "construct consisting of a number of interrelated attributes or dimensions and existing in multi-dimensional domains".)

Trumpp et al. [11] examine the validity of their own CEP constructs using exploratory and confirmatory factor analyses. They provide a multidimensional construct composed of two dimensions: The EMP dimension captures environmental objectives, environmental policy, environmental processes, environmental monitoring, and organizational structure; the EOP dimension captures energy consumption, greenhouse gas emissions, water consumption, hazardous waste, and total waste. In essence, EMP questions the management if the firm has set policies to improve environmental performance, while EOP measures actual environmental outputs of the firm. Trumpp et al. [11] build two performance construct variables for the EOP dimension, EOP1, and EOP2, considering multidimensionality. EOP1 consists of energy consumption, greenhouse gas emissions, and water consumption, whereas EOP2 consists of total waste and hazardous waste.

\section{Points of Departure}

The Korean government has been concerned with environmental issues and has regulated companies to prevent air and water pollution. The government has also provided various supports and incentives to companies that have obtained international environmental certifications such as the "ISO14001". In April of 2010, the Korean government implemented the "Framework Act on Green Growth", adding the "Green Certification System" to the previous "Environmentally Friendly Company Designation System" to provide tax incentives and investment support. In the stock market, eco-funds were listed and CSR indexes were developed. All these factors exposed firms to various environmental risks such as regulatory, economic, and litigation risks if companies fail to actively respond to environmental issues.

Corporate environmental performance may affect firm value through risk related to the environment. This risk stems from uncertainty surrounding new environmental regulations and the increased probability of future liabilities and/or reduced future earnings. For instance, the enactment of the Korea's Greenhouse Gas Emission Trading Scheme influenced the valuation process for Korean firms. (Korea enacted the Act on the Allocation and Trading of Greenhouse Gas Emission Permits in 2012 and devised the National Emission Permit Allocation Plan in 2014. The Korean Ministry of the Environment announced 'the Revised Roadmap to Achieve the National GHG Reduction Target for 2030' and 'the Second Stage Plan for National Greenhouse Gas Emission Permit Allocation during the Second Planning 
Period' [30]). Using the sample of the Australian Securities Exchange, Chapple et al. [19] investigated the effect of the introduction of an emissions trading scheme on firm valuation. They found evidence that the amount of carbon emissions is negatively related to firm value. Obviously, the association between firm value and environmental performance will depend upon the degree to which shareholders reflect environmental performance data in their firm valuations.

Based on prior literature [2,4], we conjecture that if market participants consider EPIs to be reliable and useful measures in the valuation process, EPI values will add significant value relevance to firms. According to the legitimacy theory, the level of disclosure about environmental matters within a firm is linked to its affiliated industry [31]. Empirical studies based on legitimacy theory show that firms in "environmentally sensitive" industries (i.e., those with manufacturing processes that have a significantly negative impact on the environment), such as the chemical, oil, mining, metal, paper, and pulp industries, disclose more environmental information compared to those in other industries [32]. Pollution, waste management, and consumption of natural resources resulting from their operations are all important in these industries. Consequently, environmentally sensitive industries often face greater litigation risk and are more vulnerable to public criticism [3]. Reverte [33] presents anecdotal evidence that CSR information has higher incremental value relevance among firms in environmentally sensitive industries.

\section{Research Design}

\subsection{Sample and Data}

Data for sample firms are derived from the Korea Composite Stock Price Index (KOSPI) and the Korea Securities Dealers Automated Quotations (KOSDAQ) for the years 2009 to 2013. Financial data, such as market value, book value, and net income, are obtained from the FnGuide database. Environmental performance data are obtained from the ASSET4 database, since it provides comprehensive environmental performance data gathered from various sources including corporate websites, sustainability reports, and annual reports [11]. Merging financial statement data and environmental performance data yields a total of 218 firm-year observations available for the analysis.

\subsection{Research Method}

The value relevance model presented herein is based on the implementation of the Ohlson model [12], which is a simple Linear Least Square (LLR) regression analysis. In the Ohlson model, firm market value is a function of a firm's book value and its net income (i.e., earnings). Similar to the protocol in prior literature [4], we add variables related to EPIs and EPCs to investigate how investors value information related to environmental performance. The basic idea behind the equation is that since the bulk of valuation is theoretically allocated to firm's book value and to the firm's net income, additional value relevant factor(s) that should be of interest when it is statistically significant in addition to the two main anchors of valuation.

This paper investigates the value relevance of CEP, including individual environmental performance indicators (EPI), as well as a composite measure of environmental performance constructs (EPC) derived from Trumpp et al. [11]. The composite measure of CEP may alleviate some concerns of multicollinearity since the composite measure (EPC) is a standardized measure from sum of individual measures (EPI). In this analysis, the incremental value relevance of environmental performance is examined using the framework for CEP presented in Trumpp et al. [11].

Following prior research [2,4], we model the value relevance of the CEP variable by adopting individual EPIs and composite EPCs for reasons mentioned above. Equation (1) is as follows:

$$
M V_{i t}=\alpha_{0}+\alpha_{1} A S S E T_{i t}+\alpha_{2} L I A B_{i t}+\alpha_{3} N I_{i t}+\sum \beta \times C E P_{i t}+\varepsilon_{i t}
$$

where $M V_{i t}$ is the market value of common equity, which is a product of price per share and the number of common shares outstanding, ASSET $i t$ is total assets, $L I A B_{i t}$ is liabilities, and $N I_{i t}$ is net income in 
millions of Korean won. Since a firm's book value is its assets less liabilities, the model utilizes assets and liabilities accounts instead of book values, because book values often have small or negative values. We expect positive coefficients for $A S S E T_{i t}$ and $N I_{i t}$ and a negative coefficient for $L I A B_{i t}$.

We do not scale $M V_{i t}, A S S E T_{i t}, L I A B_{i t}$, and $N I_{i t}$ in this model, since Barth and Clinch [34] foundd that unscaled values are generally superior to scaled values in estimation models. Moreover, Ziliak and McCloskey [35] argue that an unscaled model produces more intuitive and economically meaningful coefficients. We include year dummies and industry dummies at the two-digit Korea Standard Industry Code level to control for year fixed effects as well as industry fixed effects.

The variable of interest, $C E P_{i t}$, represents CEP indicators for EOP and EMP dimensions, as obtained from the ASSET4 database [11,36]. Appendix A provides information on the data source of ASSET4 database. Following prior studies, we obtain a performance construct variable for the EMP dimension by summing up the items capturing a firm's environmental management and environmental policy. Detailed definitions of the individual EPI variables are presented in Table 1.

Table 1. Environmental performance indicators (EPI) variables.

\begin{tabular}{|c|c|c|c|}
\hline EPI Variable & ASSET4 Item & Question Presented in ASSET4 & Coding of ASSET4 \\
\hline \multicolumn{4}{|c|}{ Environmental management performance (EMP) } \\
\hline POL1 & ENRRDP0012 & Does the company have a policy to improve its energy efficiency? & Yes: 1, No: 0 \\
\hline PRO & ENRRDP058 & $\begin{array}{l}\text { Does the company use environmental criteria (ISO 14000, energy consumption, } \\
\text { etc.) in the selection process of its suppliers or sourcing partners? }\end{array}$ & Yes: 1 , No: 0 \\
\hline \multicolumn{4}{|c|}{ Environmental operational performance (EOP) } \\
\hline ENERGY & ENRRDP033 & Total direct and indirect energy consumption in gigajoules & Continuous data \\
\hline WASTE & ENERDP045 & Total amount of waste produced in thousand tons & Continuous data \\
\hline WATER & ENRRDP054 & Total water withdrawal in million cubic meters & Continuous data \\
\hline HAZ_WASTE & ENERDP056 & Total amount of hazardous waste produced in thousand tons & Continuous data \\
\hline
\end{tabular}

EPCs are computed using the average of the standardized indicators associated with each dimension [37]. Larcker et al. [37] computed corporate governance scores as "the average equal-weighted sum of the standardized indicators associated with each factor" after conducting a Principal Component Analysis (PCA) to identify factors which have an eigenvalue larger than 1 . Our goal here is to construct three standardized composite measures from eight individual indicators. We compute the EMP variable as the sum of two variables, energy efficiency policy (POL1) and water efficiency policy (POL2), and environmental processes (PRO), divided by three. Consistent with Trumpp et al. [11], two EOP variables are calculated using respective standardized indicators as follows to reflect multi-dimensionality: EOP1 is the sum of a standardized variable representing direct and indirect energy consumption (ENERGY), a standardized variable representing water usage (WATER), and a variable representing greenhouse gases, GHG, divided by three. EOP2 is the sum of a standardized variable representing the amount of waste produced (WASTE) and a variable representing hazardous waste, HAZ_WASTE, divided by two. Since these variables are weighted combinations of standardized variables, the mean value for each variable is equal to zero.

Trumpp and Guenther [38] investigated the relationship between two environmental aspects (i.e., carbon performance and waste intensity for which data were broadly available) and firm performance, while we attempt to investigate corporate environmental performance comprehensively in relation to value relevance. Trumpp and Guenther [38] went beyond Trumpp et al. [11], and explored the non-linear relationship between corporate environmental performance and corporate financial performance, and found a U-shape association. This study does not test the non-linear relationship since the main independent variable is a standardized composite measure of CEP.

\section{Empirical Results}

Table 2 presents the descriptive statistics. On average, sample firms have a market capitalization of KRW 10.75 billion. Average values for the book value of assets, liabilities, and earnings are 22.28, 12.24, 
and 0.96 billion KRW, respectively. Table 3 shows the Pearson correlation coefficients among variables. It is worthwhile to note that many values for the EPI variables are considerably skewed, as described above. EPI variables and MV (market value) are positively correlated, which indicates that firms with higher market values are more likely to have higher values for EMP and EOP. The correlations between EMP variables (e.g., POL1 and POL2) are positive and significant, suggesting that firms with energy efficiency policies are more likely to have water efficiency policies as well. The correlations between EOP variables (e.g., GHG and ENERGY) show similar patterns. Among the EPI variables, the correlations between EMP variables and EOP variables are positive, implying that firms with higher values for environmental management performance also have higher values for environmental operational performance.

Table 2. Descriptive statistics. MV: Market value.

\begin{tabular}{ccccccc}
\hline & N & MEAN & SD & Q1 & MEDIAN & Q3 \\
\hline MV & 218 & 10.75 & 11.28 & 3.72 & 6.97 & 12.08 \\
ASSET & 218 & 22.28 & 30.30 & 6.80 & 12.36 & 25.47 \\
LIAB & 218 & 12.24 & 15.05 & 3.09 & 7.74 & 15.55 \\
NI & 218 & 0.96 & 1.43 & 0.21 & 0.46 & 1.11 \\
POL1 & 218 & 1 & 0 & 0 & 1 & 1 \\
POL2 & 218 & 1 & 0 & 1 & 1 & 1 \\
PRO & 218 & 1 & 0 & 0 & 1 & 1 \\
GHG & 218 & 2.71 & 3.71 & 0.15 & 0.83 & 4.28 \\
ENERGY & 218 & 61.59 & 112.61 & 1.25 & 9.03 & 61.09 \\
WASTE & 218 & 136.31 & 207.19 & 1.65 & 39.33 & 170.11 \\
WATER & 218 & 13.22 & 19.98 & 0.55 & 2.84 & 16.99 \\
HAZ_WASTE & 218 & 2.92 & 8.63 & 0.25 & 0.54 & 4.33 \\
\hline
\end{tabular}

Tables 4 and 5 reports the results of the mean difference test to evaluate the differences in the variables occluded in the valuation model between two groups divided by EPI variables as follows: EMP and non-EMP, low-EOP and high-EOP. Differences in the mean values are evaluated via $t$-tests. Table 4 shows the differences in means of the market value of equity, total assets, liabilities, and net incomes for the dimensions of EMP $($ EMP $=1)$ and non-EMP $(E M P=0)$ firms. Firms with an energy efficiency policy (POL1 =1) have a mean value (standard deviation) for MV of 13.86 (13.55) and the mean value (standard deviation) for MV for firms without an energy efficiency policy (POL1 $=0$ ) is 6.803 (5.377). Similarly, the mean values of MV differ between two groups, divided by POL2 and $\mathrm{PRO}$, respectively. The $t$-test results show that the means of MV differ significantly between these two groups, indicating that the market values of EMP firms are significantly higher than those of non-EMP firms. Table 4 further shows that EMP firms have higher values for ASSET and NI than non-EMP firms, but the significance levels are lower. The means of LIAB do not differ significantly among all cases.

Table 5 illustrates the differences in means of MV, total assets, liabilities, and net incomes in the dimension of low-EOP (below median) and high-EOP (above median) firms. We divide the sample into two groups based on the median values of EOP variables. Firms with low greenhouse gas emissions (low-GHG) have a mean value (standard deviation) for MV of 7.20 (5.43) and the mean value (standard deviation) for MV for firms with high greenhouse gas emissions (high-GHG) is 14.31 (14.17). Similarly, the mean values of MV differ between two groups divided by ENERGY, WATER, and WASTE, respectively. The $t$-test results show that the means of MV differ significantly between the two groups, indicating that low-EOP firms have significantly lower market values than high-EOP firms. Table 5 further shows that low-EOP firms have significantly lower values for ASSET, LIAB, and NI than high-EOP firms. 
Table 3. Pearson correlations.

\begin{tabular}{|c|c|c|c|c|c|c|c|c|c|c|c|c|}
\hline & MV & ASSET & LIAB & NI & POL1 & POL2 & PRO & GHG & ENERGY & WASTE & WATER & HAZ_WASTE \\
\hline MV & 1 & & & & & & & & & & & \\
\hline ASSET & $0.810^{* * *}$ & 1 & & & & & & & & & & \\
\hline LIAB & $0.668^{* * *}$ & $0.909 * * *$ & 1 & & & & & & & & & \\
\hline NI & $0.909 * * *$ & $0.788^{* * *}$ & $0.673^{* * *}$ & 1 & & & & & & & & \\
\hline POL1 & $0.311^{* * *}$ & $0.160 *$ & 0.0773 & $0.245^{* * *}$ & 1 & & & & & & & \\
\hline POL2 & $0.172 *$ & 0.109 & 0.0834 & 0.13 & $0.338^{* * *}$ & 1 & & & & & & \\
\hline PRO & $0.234^{* * *}$ & $0.138^{*}$ & 0.0938 & $0.148^{*}$ & $0.336^{* * *}$ & $0.286^{* * *}$ & 1 & & & & & \\
\hline GHG & $0.334^{* * *}$ & $0.363^{* * *}$ & $0.283^{* * *}$ & $0.249 * * *$ & -0.0687 & $0.161^{*}$ & 0.144 * & 1 & & & & \\
\hline ENERGY & $0.435^{* * *}$ & $0.491^{* * *}$ & $0.318^{* * *}$ & $0.374^{* * *}$ & 0.124 & $0.144 *$ & 0.0745 & $0.536^{* * *}$ & 1 & & & \\
\hline WASTE & $0.437^{* * *}$ & $0.507^{* * *}$ & $0.448^{* * *}$ & $0.388^{* * *}$ & $0.224^{* * *}$ & $0.167^{*}$ & 0.0837 & $0.156^{*}$ & $0.239 * * *$ & 1 & & \\
\hline WATER & $0.566^{* * *}$ & $0.514^{* * *}$ & $0.359^{* * *}$ & $0.441^{* * *}$ & $0.236^{* * *}$ & $0.195^{* *}$ & 0.113 & $0.653^{* * *}$ & $0.520 * * *$ & $0.323^{* * *}$ & 1 & \\
\hline HAZ_WASTE & $0.172 *$ & 0.143 * & 0.0797 & 0.08 & 0.109 & 0.0781 & 0.12 & $0.304^{* * *}$ & 0.136 * & 0.0671 & $0.468^{* * *}$ & 1 \\
\hline
\end{tabular}

Table 4. Univariate tests for firm market value and environmental performance: Dimension of EMP $(E M P=1)$ and Non-EMP $(E M P=0)$.

\begin{tabular}{|c|c|c|c|c|c|c|c|c|c|}
\hline & POL1 & Non-POL1 & $t$-Tests & POL2 & Non-POL2 & $t$-Tests & PRO & Non-PRO & $t$-Tests \\
\hline & $\begin{array}{l}\text { Mean } \\
\text { (S.D.) }\end{array}$ & $\begin{array}{l}\text { Mean } \\
\text { (S.D.) }\end{array}$ & $\begin{array}{c}\text { Diff } \\
(t \text {-stat. })\end{array}$ & $\begin{array}{l}\text { Mean } \\
\text { (S.D.) }\end{array}$ & $\begin{array}{l}\text { Mean } \\
\text { (S.D.) }\end{array}$ & $\begin{array}{c}\text { Diff } \\
(t \text {-stat. })\end{array}$ & $\begin{array}{l}\text { Mean } \\
\text { (S.D.) }\end{array}$ & $\begin{array}{l}\text { Mean } \\
\text { (S.D.) }\end{array}$ & $\begin{array}{c}\text { Diff } \\
(t \text {-stat. })\end{array}$ \\
\hline MV & $\begin{array}{c}13.86 \\
(13.55)\end{array}$ & $\begin{array}{c}6.803 \\
(5.377)\end{array}$ & $\begin{array}{c}7.058^{* * *} \\
(4.81)\end{array}$ & $\begin{array}{c}11.33 \\
(11.58)\end{array}$ & $\begin{array}{c}4.289 \\
(2.782)\end{array}$ & $\begin{array}{c}7.046^{*} \\
(2.57)\end{array}$ & $\begin{array}{c}12.28 \\
(12.28)\end{array}$ & $\begin{array}{c}6.228 \\
(5.618)\end{array}$ & $\begin{array}{c}6.052^{* * *} \\
(3.53)\end{array}$ \\
\hline ASSET & $\begin{array}{c}26.57 \\
(37.80)\end{array}$ & $\begin{array}{c}16.83 \\
(14.93)\end{array}$ & $\begin{array}{c}9.735 * \\
(2.38)\end{array}$ & $\begin{array}{c}23.27 \\
(30.67)\end{array}$ & $\begin{array}{l}11.26 \\
(23.74)\end{array}$ & $\begin{array}{l}12.01 \\
(1.62)\end{array}$ & $\begin{array}{c}24.71 \\
(33.37)\end{array}$ & $\begin{array}{c}15.08 \\
(16.68)\end{array}$ & $\begin{array}{c}9.635 * \\
(2.05)\end{array}$ \\
\hline LIAB & $\begin{array}{c}13.27 \\
(17.05)\end{array}$ & $\begin{array}{c}10.93 \\
(12.02)\end{array}$ & $\begin{array}{l}2.339 \\
(1.14)\end{array}$ & $\begin{array}{c}12.61 \\
(14.35)\end{array}$ & $\begin{array}{c}8.059 \\
(21.49)\end{array}$ & $\begin{array}{l}4.554 \\
(1.23)\end{array}$ & $\begin{array}{c}13.06 \\
(15.41)\end{array}$ & $\begin{array}{c}9.811 \\
(13.80)\end{array}$ & $\begin{array}{l}3.244 \\
(1.38)\end{array}$ \\
\hline NI & $\begin{array}{c}1.272 \\
(1.733)\end{array}$ & $\begin{array}{c}0.565 \\
(0.767)\end{array}$ & $\begin{array}{c}0.707^{* * * *} \\
(3.72)\end{array}$ & $\begin{array}{c}1.016 \\
(1.483)\end{array}$ & $\begin{array}{c}0.339 \\
(0.242)\end{array}$ & $\begin{array}{l}0.678 \\
(1.93)\end{array}$ & $\begin{array}{c}1.083 \\
(1.580)\end{array}$ & $\begin{array}{c}0.596 \\
(0.767)\end{array}$ & $\begin{array}{c}0.487^{*} \\
(2.20)\end{array}$ \\
\hline Observations & 122 & 96 & 218 & 200 & 18 & 218 & 163 & 55 & 218 \\
\hline
\end{tabular}

$t$ statistics in parentheses; ${ }^{*} p<0.1,{ }^{* *} p<0.05,{ }^{* * *} p<0.01$. 
Table 5. Univariate tests for firm market value and environmental performance: Dimension of low-EOP (below median) and high-EOP (above median).

\begin{tabular}{|c|c|c|c|c|c|c|c|c|c|c|c|c|}
\hline & \multirow{2}{*}{$\begin{array}{c}\text { Low-GHG } \\
\text { Mean } \\
\text { (S.D.) }\end{array}$} & \multirow{2}{*}{$\begin{array}{c}\text { High-GHG } \\
\text { Mean } \\
\text { (S.D.) }\end{array}$} & \multirow{2}{*}{$\begin{array}{c}t \text {-Tests } \\
\begin{array}{c}\text { Diff } \\
(t \text {-stat. })\end{array}\end{array}$} & \multirow{2}{*}{$\begin{array}{c}\text { Low-ENERGY } \\
\text { Mean } \\
\text { (S.D.) }\end{array}$} & \multirow{2}{*}{$\begin{array}{c}\text { High-ENERGY } \\
\text { Mean } \\
\text { (S.D.) }\end{array}$} & \multirow{2}{*}{$\begin{array}{c}t \text {-Tests } \\
\begin{array}{c}\text { Diff } \\
(t \text {-stat. })\end{array}\end{array}$} & \multirow{2}{*}{$\begin{array}{c}\text { Low-WATER } \\
\text { Mean } \\
\text { (S.D.) }\end{array}$} & \multirow{2}{*}{$\begin{array}{l}\text { High-WATER } \\
\text { Mean } \\
\text { (S.D.) }\end{array}$} & \multirow{2}{*}{$\begin{array}{c}t \text {-Tests } \\
\begin{array}{c}\text { Diff } \\
(t \text {-stat. })\end{array}\end{array}$} & \multicolumn{2}{|c|}{ Low-WASTE High-WASTE } & \multirow{2}{*}{$\begin{array}{c}t \text {-Tests } \\
\begin{array}{c}\text { Diff } \\
(t \text {-stat. })\end{array}\end{array}$} \\
\hline & & & & & & & & & & $\begin{array}{l}\text { Mean } \\
\text { (S.D.) }\end{array}$ & $\begin{array}{l}\text { Mean } \\
\text { (S.D.) }\end{array}$ & \\
\hline MV & $\begin{array}{l}7.200 \\
(5.430)\end{array}$ & $\begin{array}{c}14.31 \\
(14.17)\end{array}$ & $\begin{array}{c}-7.107^{* * *} \\
(-4.89)\end{array}$ & $\begin{array}{c}7.898 \\
(7.483)\end{array}$ & $\begin{array}{c}13.61 \\
(13.54)\end{array}$ & $\begin{array}{c}-5.711^{* * *} \\
(-3.85)\end{array}$ & $\begin{array}{c}6.893 \\
(6.274)\end{array}$ & $\begin{array}{c}14.61 \\
(13.65)\end{array}$ & $\begin{array}{c}-7.721 * * * \\
(-5.37)\end{array}$ & $\begin{array}{l}7.963 \\
(8.711)\end{array}$ & $\begin{array}{c}13.54 \\
(12.81)\end{array}$ & $\begin{array}{c}-5.579 * * * \\
(-3.76)\end{array}$ \\
\hline ASSET & $\begin{array}{l}13.02 \\
(13.16)\end{array}$ & $\begin{array}{l}31.54 \\
(38.71)\end{array}$ & $\begin{array}{c}-18.52^{* * *} \\
(-4.73)\end{array}$ & $\begin{array}{l}15.36 \\
(15.93)\end{array}$ & $\begin{array}{l}29.21 \\
(38.65)\end{array}$ & $\begin{array}{c}-13.85^{* * *} \\
(-3.46)\end{array}$ & $\begin{array}{l}13.73 \\
(13.95)\end{array}$ & $\begin{array}{c}30.84 \\
(38.76)\end{array}$ & $\begin{array}{c}-17.11^{* * *} \\
(-4.34)\end{array}$ & $\begin{array}{l}14.56 \\
(16.67)\end{array}$ & $\begin{array}{l}30.00 \\
(38.03)\end{array}$ & $\begin{array}{c}-15.43^{* * *} \\
(-3.88)\end{array}$ \\
\hline LIAB & $\begin{array}{l}8.023 \\
(10.84)\end{array}$ & $\begin{array}{l}16.45 \\
(17.38)\end{array}$ & $\begin{array}{l}-8.427^{* * *} \\
(-4.30)\end{array}$ & $\begin{array}{c}9.680 \\
(12.12)\end{array}$ & $\begin{array}{c}14.79 \\
(17.18)\end{array}$ & $\begin{array}{c}-5.114 * \\
(-2.54)\end{array}$ & $\begin{array}{l}9.017 \\
(11.41)\end{array}$ & $\begin{array}{l}15.46 \\
(17.44)\end{array}$ & $\begin{array}{c}-6.440 * * \\
(-3.23)\end{array}$ & $\begin{array}{c}8.840 \\
(11.99)\end{array}$ & $\begin{array}{l}15.63 \\
(16.98)\end{array}$ & $\begin{array}{c}-6.793 * * * \\
(-3.41)\end{array}$ \\
\hline NI & $\begin{array}{c}0.564 \\
(0.695)\end{array}$ & $\begin{array}{l}1.357 \\
(1.824)\end{array}$ & $\begin{array}{c}-0.793 * * * \\
(-4.24)\end{array}$ & $\begin{array}{c}0.644 \\
(0.873)\end{array}$ & $\begin{array}{c}1.276 \\
(1.779)\end{array}$ & $\begin{array}{c}-0.632 * * \\
(-3.33)\end{array}$ & $\begin{array}{l}0.528 \\
(0.864)\end{array}$ & $\begin{array}{l}1.393 \\
(1.734)\end{array}$ & $\begin{array}{c}-0.865^{* * *} \\
(-4.67)\end{array}$ & $\begin{array}{c}0.651 \\
(0.992)\end{array}$ & $\begin{array}{l}1.270 \\
(1.718)\end{array}$ & $\begin{array}{c}-0.619^{* *} \\
(-3.26)\end{array}$ \\
\hline Observations & 109 & 109 & 218 & 109 & 109 & 218 & 109 & 109 & 218 & 109 & 109 & 218 \\
\hline
\end{tabular}

$t$ statistics in parentheses; ${ }^{*} p<0.1,{ }^{* *} p<0.05,{ }^{* * *} p<0.01$. 
Table 6 reports the results of the regression analysis for Equation (1). Columns 1-9 present the results from the base model adding the eight individual EPI variables, and columns 10-12 show the results from the three composite EPC variables (derived from eight individual EPI variables). Consistent with prior literature [4], the coefficients of $A S S E T_{i t}$ and $\mathrm{NI}_{i t}$, as expected, are positive and significant. It shows that firms with larger assets and higher net income values tend to have higher firm value in Korea. The coefficient of $L I A B_{i t}$ is negative and significant, which means that investors in Korean stock markets consider firms with higher liabilities in a negative way, contrary to firms with larger assets and higher net income values.

When we use the individual EPI variables that constitute a firm's environmental performance, some EPIs show additional value relevance, whereas others do not. For instance, the second column of Table 6 shows that adding the variable POL1 (energy efficiency) to the traditional Ohlson model increases the adjusted R-squared. The coefficient of POL1 $\left(\beta_{1}=2.101 ; p<0.01\right)$ is positive and significant, indicating that firm value increases by KRW 2.101 billion on average when the firm has an energy efficiency policy. Similarly, the fourth and fifth columns show that the variables PRO (environmental process) and GHG (emissions of $\mathrm{CO}_{2}$ and $\mathrm{CO}_{2}$ equivalents) both have additional value relevance and economic significance in the positive direction, respectively. The tenth and eleventh columns of Table 6 show that EMP and EOP1 have significant and positive impact on firm market value.

However, adding POL2 (water efficiency) neither increases the explanatory power, nor is the result as significant as that for POL1; rather, this variable slightly decreases the adjusted R-squared. It implies that investors do not pay much attention to whether a company has a policy to improve its water efficiency contrary to energy efficiency. The variables ENERGY (direct and indirect energy consumption) and WASTE (amount of waste produced) neither show significant results nor do they increase the value of the adjusted R-squared. These results may imply that the bulk of firm market values are explained by assets, liabilities, and net income, as argued by Ohlson (1995), while other factors such as corporate environmental performance seldom incrementally add to value relevance in significant amounts. However, we conjecture that these results stem from 'multicollinearity', which refers to a condition in which two or more explanatory variables are strongly linearly related in the multiple regression model. Interestingly, we find high multicollinearity in the sixth and eighth columns. Variance inflation factors (VIFs) range from 14.45 to 17.04 for GHG and have a value of 12.08 for HAZ_WASTE. Typically, multicollinearity is considered problematic (very problematic) when VIFs exceed 10 (20) [39]. Thus, multicollinearity is high due to the inclusion of WATER and HAZ_WASTE in the regression model. In contrast, the VIFs are low in the regression model, adopting EPCs instead of EPI variables. Column 12 of Table 6 shows that the VIFs of EMP, EOP1, and EOP2 are 1.71, 4.16, and 2.90, respectively, much lower than those of EPI variables. Song et al. [40] cautioned that researchers should use composite variables carefully because of the loss of information as the consequence of combining different variables. However, they also argued that using PCA grouped composite variables may reduce multicollinearity.

Tables 7 and 8 present the regression results of Equation (1) for firms in environmentally sensitive industries and for firms in other industries, respectively. We divide the entire sample into two groups by affiliated industries and conduct the same analyses to examine whether the value relevance of a firm's environmental information depends on its affiliated industry. Table 7 shows that the coefficients for the EPI and EPC variables are significant only among firms in environmentally sensitive industries. Table 7 reveals that for firms in environmentally sensitive industries, POL1, ENERGY, WATER, and WASTE have additional value relevance among the individual EPI variables. With regard to economic significance, on average, firm value increases by KRW 2.997 billion for firms in environmentally sensitive industries with an energy efficiency policy. However, investors do not pay much attention to whether a company has a policy to improve its water efficiency, similarly to the results in Table 6. Three other variables, ENERGY, WATER, and WASTE, are shown to have significant economic impacts on firm value as well as increasing the explanatory power of the model. Column 13 of Table 7 shows that three EPCs-EMP, EOP1, and EOP2 - have significant and positive impacts on firm market value, while EOP1 and EOP2 seem to offset each other. Table 8 shows that none of the EPIs/EPCs have a significant impact on firm value. 
Table 6. Results of the regression analyses for Equation (1): $M V_{i t}=\alpha_{0}+\alpha_{1} A S S E T_{i t}+\alpha_{2} L I A B_{i t}+\alpha_{3} N I_{i t}+\sum \beta \times C E P_{i t}+\varepsilon_{i t}$.

\begin{tabular}{|c|c|c|c|c|c|c|c|c|c|c|c|c|}
\hline \multirow[b]{2}{*}{ ASSET } & \multicolumn{12}{|c|}{ Dependent Variable $=\mathrm{MV}$} \\
\hline & $\begin{array}{c}0.159 * * * \\
(4.762)\end{array}$ & $\begin{array}{c}0.156^{* * *} \\
(4.799)\end{array}$ & $\begin{array}{c}0.157^{* * *} \\
(4.789)\end{array}$ & $\begin{array}{c}0.157^{* * *} \\
(4.878)\end{array}$ & $\begin{array}{c}0.146^{* * *} \\
(4.557)\end{array}$ & $\begin{array}{c}0.172^{* * *} \\
(4.521)\end{array}$ & $\begin{array}{c}0.135 * * * \\
(4.270)\end{array}$ & $\begin{array}{c}0.152 * * * \\
(4.580)\end{array}$ & $\begin{array}{c}0.149^{* * *} \\
(4.628)\end{array}$ & $\begin{array}{c}0.158 * * * \\
(4.877)\end{array}$ & $\begin{array}{c}0.127 * * * \\
(3.812)\end{array}$ & $\begin{array}{c}0.127^{* * * *} \\
(3.800)\end{array}$ \\
\hline LIAB & $\begin{array}{c}-0.141^{* * *} \\
(-2.619)\end{array}$ & $\begin{array}{c}-0.130^{* *} \\
(-2.451)\end{array}$ & $\begin{array}{l}-0.129^{* *} \\
(-2.431)\end{array}$ & $\begin{array}{c}-0.127^{* *} \\
(-2.436)\end{array}$ & $\begin{array}{c}-0.120^{* *} \\
(-2.328)\end{array}$ & $\begin{array}{c}-0.153^{* * * *} \\
(-2.646)\end{array}$ & $\begin{array}{l}-0.110^{* *} \\
(-2.172)\end{array}$ & $\begin{array}{l}-0.121^{* *} \\
(-2.344)\end{array}$ & $\begin{array}{c}-0.123 * * \\
(-2.383)\end{array}$ & $\begin{array}{l}-0.126^{* *} \\
(-2.399)\end{array}$ & $\begin{array}{l}-0.096^{*} \\
(-1.836)\end{array}$ & $\begin{array}{l}-0.097^{*} \\
(-1.829)\end{array}$ \\
\hline NI & $\begin{array}{l}4.904 * * * \\
(11.258)\end{array}$ & $\begin{array}{l}4.773 * * * \\
(11.143)\end{array}$ & $\begin{array}{l}4.766^{* * *} \\
(11.064)\end{array}$ & $\begin{array}{l}4.694^{* * *} \\
(11.050)\end{array}$ & $\begin{array}{l}4.494^{* * *} \\
(10.515)\end{array}$ & $\begin{array}{l}4.494^{* * *} \\
(10.530)\end{array}$ & $\begin{array}{l}4.445^{* * *} \\
(10.661)\end{array}$ & $\begin{array}{l}4.465^{* * * *} \\
(10.383)\end{array}$ & $\begin{array}{l}4.531^{* * *} \\
(10.562)\end{array}$ & $\begin{array}{l}4.689^{* * * *} \\
(10.995)\end{array}$ & $\begin{array}{l}4.467^{* * *} \\
(10.493)\end{array}$ & $\begin{array}{l}4.471^{* * *} \\
(10.368)\end{array}$ \\
\hline POL1 & & $\begin{array}{c}2.101^{* * *} \\
(3.059)\end{array}$ & $\begin{array}{c}2.067^{* * * *} \\
(2.913)\end{array}$ & $\begin{array}{l}1.476^{* *} \\
(2.021)\end{array}$ & $\begin{array}{l}1.722 * * \\
(2.366)\end{array}$ & $\begin{array}{l}1.703 * * \\
(2.341)\end{array}$ & $\begin{array}{c}1.044 \\
(1.412)\end{array}$ & $\begin{array}{l}1.821^{* * *} \\
(2.453)\end{array}$ & $\begin{array}{l}1.668^{* *} \\
(2.285)\end{array}$ & & & \\
\hline POL2 & & & $\begin{array}{c}0.261 \\
(0.200)\end{array}$ & & & & & & & & & \\
\hline PRO & & & & $\begin{array}{c}1.909 * * \\
(2.328)\end{array}$ & $\begin{array}{l}1.554^{*} \\
(1.888)\end{array}$ & $\begin{array}{l}1.588^{*} \\
(1.931)\end{array}$ & $\begin{array}{l}1.870^{* *} \\
(2.314)\end{array}$ & $\begin{array}{l}1.549^{*} \\
(1.880)\end{array}$ & $\begin{array}{l}1.619^{*} \\
(1.962)\end{array}$ & & & \\
\hline GHG & & & & & $\begin{array}{l}0.310^{* *} \\
(2.417)\end{array}$ & $\begin{array}{c}0.413 * * * \\
(2.714)\end{array}$ & $\begin{array}{l}-0.112 \\
(-0.619)\end{array}$ & $\begin{array}{l}0.308 \text { ** } \\
(2.394)\end{array}$ & $\begin{array}{c}0.239 \\
(1.626)\end{array}$ & & & \\
\hline ENERGY & & & & & & $\begin{array}{l}-0.008 \\
(-1.252)\end{array}$ & & & & & & \\
\hline WATER & & & & & & & $\begin{array}{c}0.092 * * * \\
(3.262)\end{array}$ & & & & & \\
\hline WASTE & & & & & & & & $\begin{array}{l}-0.001 \\
(-0.708)\end{array}$ & & & & \\
\hline HAZ_WASTE & & & & & & & & & $\begin{array}{c}0.043 \\
(1.004)\end{array}$ & & & \\
\hline EMP & & & & & & & & & & $\begin{array}{c}4.065 \text { *** } \\
(3.607)\end{array}$ & $\begin{array}{c}3.758^{* * *} \\
(3.381)\end{array}$ & $\begin{array}{c}3.751^{* * *} \\
(3.353)\end{array}$ \\
\hline EOP1 & & & & & & & & & & & $\begin{array}{c}1.506^{* * * *} \\
(2.854)\end{array}$ & $\begin{array}{l}1.488^{* *} \\
(2.545)\end{array}$ \\
\hline EOP2 & & & & & & & & & & & & $\begin{array}{c}0.039 \\
(0.070)\end{array}$ \\
\hline Constant & $\begin{array}{c}-0.011 \\
(-0.004)\end{array}$ & $\begin{array}{c}-0.204 \\
(-0.079)\end{array}$ & $\begin{array}{l}-0.481 \\
(-0.163)\end{array}$ & $\begin{array}{l}-1.857 \\
(-0.698)\end{array}$ & $\begin{array}{l}-1.515 \\
(-0.577)\end{array}$ & $\begin{array}{l}-1.432 \\
(-0.545)\end{array}$ & $\begin{array}{c}-1.793 \\
(-0.700)\end{array}$ & $\begin{array}{c}-1.680 \\
(-0.636)\end{array}$ & $\begin{array}{c}-1.489 \\
(-0.567) \\
\end{array}$ & $\begin{array}{l}-2.801 \\
(-1.045)\end{array}$ & $\begin{array}{c}-1.759 \\
(-0.662) \\
\end{array}$ & $\begin{array}{l}-1.730 \\
(-0.641)\end{array}$ \\
\hline Variance inflation factors ( & & & & & & & & & & & & \\
\hline GHG & & & & & & & 17.04 & & 14.45 & & & \\
\hline WATER & & & & & & & 5.04 & & & & & \\
\hline HAZ_WASTE & & & & & & & & & 12.08 & & & \\
\hline EMP & & & & & & & & & & 1.68 & 1.70 & 1.71 \\
\hline EOP1 & & & & & & & & & & & 3.41 & 4.16 \\
\hline EOP2 & & & & & & & & & & & & 2.90 \\
\hline Observations & 218 & 218 & 218 & 218 & 218 & 218 & 218 & 218 & 218 & 218 & 218 & 218 \\
\hline Adjusted R-squared & 0.825 & 0.831 & 0.830 & 0.833 & 0.836 & 0.837 & 0.842 & 0.836 & 0.836 & 0.833 & 0.837 & 0.837 \\
\hline
\end{tabular}

$t$ statistics in parentheses; ${ }^{*} p<0.1^{* *} p<0.05, * * * p<0.01$ 
Table 7. Results of the regression analysis for Equation (1) by affiliated industries: Firms in environmentally sensitive industries (ENV_IND $=1$ ). $M V_{i t}=$ $\alpha_{0}+\alpha_{1} A_{S S E T_{i t}}+\alpha_{2} L I A B_{i t}+\alpha_{3} N_{i t}+\sum \beta \times C E P_{i t}+\varepsilon_{i t}$.

\begin{tabular}{|c|c|c|c|c|c|c|c|c|c|c|c|c|c|}
\hline \multirow[b]{2}{*}{ ASSET } & \multicolumn{13}{|c|}{ Dependent Variable $=\mathrm{MV}$} \\
\hline & $\begin{array}{c}0.284^{* *} \\
(2.478)\end{array}$ & $\begin{array}{c}0.241^{* *} \\
(2.196)\end{array}$ & $\begin{array}{c}0.241^{* *} \\
(2.163)\end{array}$ & $\begin{array}{l}0.190^{*} \\
(1.708)\end{array}$ & $\begin{array}{c}0.250^{* * *} \\
(2.192)\end{array}$ & $\begin{array}{c}0.456^{* * *} \\
(4.332)\end{array}$ & $\begin{array}{c}0.426 * * * \\
(4.518)\end{array}$ & $\begin{array}{c}0.482 * * * \\
(5.286)\end{array}$ & $\begin{array}{c}0.575 * * * \\
(6.094)\end{array}$ & $\begin{array}{l}0.209^{*} \\
(1.900)\end{array}$ & $\begin{array}{c}0.274^{* *} \\
(2.311)\end{array}$ & $\begin{array}{l}0.206^{*} \\
(1.855)\end{array}$ & $\begin{array}{c}0.358 * * * \\
(3.028)\end{array}$ \\
\hline LIAB & $\begin{array}{c}-0.384 * * * \\
(-2.739)\end{array}$ & $\begin{array}{c}-0.315^{* *} \\
(-2.318)\end{array}$ & $\begin{array}{c}-0.313^{* *} \\
(-2.239)\end{array}$ & $\begin{array}{l}-0.250^{*} \\
(-1.807)\end{array}$ & $\begin{array}{c}-0.326 * * \\
(-2.308)\end{array}$ & $\begin{array}{c}-0.545^{* * * *} \\
(-4.314)\end{array}$ & $\begin{array}{c}-0.493 * * * \\
(-4.341)\end{array}$ & $\begin{array}{c}-0.560^{* * *} \\
(-5.101)\end{array}$ & $\begin{array}{c}-0.652^{* * *} \\
(-5.905)\end{array}$ & $\begin{array}{l}-0.262 * \\
(-1.898)\end{array}$ & $\begin{array}{c}-0.337^{* *} \\
(-2.295)\end{array}$ & $\begin{array}{l}-0.258^{*} \\
(-1.851)\end{array}$ & $\begin{array}{c}-0.4333^{* * *} \\
(-2.975)\end{array}$ \\
\hline NI & $\begin{array}{c}9.007^{* * *} \\
(8.463)\end{array}$ & $\begin{array}{c}8.519 * * * \\
(8.288)\end{array}$ & $\begin{array}{c}8.520 * * * \\
(8.184)\end{array}$ & $\begin{array}{c}8.480 * * * \\
(8.441)\end{array}$ & $\begin{array}{c}8.682 * * * \\
(7.587)\end{array}$ & $\begin{array}{l}8.985 * * * \\
(10.332)\end{array}$ & $\begin{array}{c}7.1911^{* * *} \\
(7.622)\end{array}$ & $\begin{array}{c}8.617 * * * \\
(8.190)\end{array}$ & $\begin{array}{c}7.310^{* * *} \\
(6.453)\end{array}$ & $\begin{array}{c}8.528^{* * *} \\
(8.490)\end{array}$ & $\begin{array}{c}9.202 * * * \\
(8.311)\end{array}$ & $\begin{array}{c}8.530^{* * * *} \\
(8.420)\end{array}$ & $\begin{array}{c}10.257^{* * *} \\
(8.938)\end{array}$ \\
\hline POL1 & & $\begin{array}{c}2.997^{* *} \\
(2.400)\end{array}$ & $\begin{array}{c}2.971 \text { ** } \\
(2.201)\end{array}$ & $\begin{array}{c}1.631 \\
(1.117)\end{array}$ & $\begin{array}{c}3.002 * * \\
(2.377)\end{array}$ & $\begin{array}{c}3.331 * * * \\
(3.169)\end{array}$ & $\begin{array}{c}3.081 * * * \\
(3.279)\end{array}$ & $\begin{array}{c}3.087 * * * \\
(3.505)\end{array}$ & $\begin{array}{c}3.478 * * * \\
(4.113)\end{array}$ & & & & \\
\hline POL2 & & & $\begin{array}{c}0.146 \\
(0.055)\end{array}$ & & & & & & & & & & \\
\hline PRO & & & & $\begin{array}{l}2.825^{*} \\
(1.700)\end{array}$ & & & & & & & & & \\
\hline GHG & & & & & $\begin{array}{l}-0.090 \\
(-0.340)\end{array}$ & & & & & & & & \\
\hline ENERGY & & & & & & $\begin{array}{c}-0.029^{* * *} \\
(-4.219)\end{array}$ & $\begin{array}{c}-0.041^{* * *} \\
(-5.759)\end{array}$ & $\begin{array}{c}-0.049^{* * *} \\
(-6.616)\end{array}$ & $\begin{array}{c}-0.045^{* * *} \\
(-6.219)\end{array}$ & & & & \\
\hline WATER & & & & & & & $\begin{array}{c}0.129^{* * *} \\
(3.334)\end{array}$ & $\begin{array}{l}0.084^{* *} \\
(2.079)\end{array}$ & $\begin{array}{c}0.047 \\
(1.148)\end{array}$ & & & & \\
\hline WASTE & & & & & & & & $\begin{array}{l}0.008^{* *} \\
(2.502)\end{array}$ & $\begin{array}{c}0.005 \\
(1.586)\end{array}$ & & & & \\
\hline HAZ_WASTE & & & & & & & & & $\begin{array}{c}0.530^{* *} \\
(2.384)\end{array}$ & & & & \\
\hline EMP & & & & & & & & & & $\begin{array}{c}5.157^{* * * *} \\
(2.734)\end{array}$ & $\begin{array}{c}5.334 * * * \\
(2.852)\end{array}$ & $\begin{array}{c}5.116^{* *} \\
(2.687)\end{array}$ & $\begin{array}{c}5.393 * * * \\
(3.036)\end{array}$ \\
\hline EOP1 & & & & & & & & & & & $\begin{array}{c}-1.358 \\
(-1.378)\end{array}$ & & $\begin{array}{c}-3.460 * * \\
(-2.642)\end{array}$ \\
\hline EOP2 & & & & & & & & & & & & $\begin{array}{c}0.610 \\
(0.578)\end{array}$ & $\begin{array}{c}3.155^{* *} \\
(2.293)\end{array}$ \\
\hline Constant & $\begin{array}{l}4.420 * * \\
(2.070)\end{array}$ & $\begin{array}{l}5.141^{* *} \\
(2.516)\end{array}$ & $\begin{array}{c}4.983 \\
(1.408)\end{array}$ & $\begin{array}{c}2.344 \\
(0.906)\end{array}$ & $\begin{array}{l}5.694^{* *} \\
(2.166)\end{array}$ & $\begin{array}{l}4.288 \text { ** } \\
(2.484)\end{array}$ & $\begin{array}{c}2.649 \\
(1.640)\end{array}$ & $\begin{array}{l}2.738^{*} \\
(1.809)\end{array}$ & $\begin{array}{l}4.146 \text { ** } \\
(2.685)\end{array}$ & $\begin{array}{c}1.550 \\
(0.690)\end{array}$ & $\begin{array}{c}1.555 \\
(0.700)\end{array}$ & $\begin{array}{c}1.898 \\
(0.810)\end{array}$ & $\begin{array}{c}3.365 \\
(1.495)\end{array}$ \\
\hline \multicolumn{14}{|c|}{ Variance inflation factors (VIFs) } \\
\hline POL1 & & & & 12.38 & 4.66 & & & & & & & & \\
\hline PRO & & & & 8.41 & & & & & & & & & \\
\hline GHG & & & & & 14.81 & & & & & & & & \\
\hline \multicolumn{14}{|l|}{ ENERGY } \\
\hline WATER & & & & & & & & & 9.03 & & & & \\
\hline WASTE & & & & & & & & & 14.54 & & & & \\
\hline EMP & & & & & & & & & & 1.56 & 1.57 & 1.56 & 1.57 \\
\hline EOP1 & & & & & & & & & & & 5.37 & & 5.54 \\
\hline EOP2 & & & & & & & & & & & & 1.44 & 2.83 \\
\hline Observations & 51 & 51 & 51 & 51 & 51 & 51 & 51 & 51 & 51 & 51 & 51 & 51 & 51 \\
\hline Adjusted R-squared & 0.816 & 0.828 & 0.826 & 0.833 & 0.826 & 0.858 & 0.873 & 0.880 & 0.886 & 0.852 & 0.874 & 0.870 & 0.884 \\
\hline
\end{tabular}


Table 8. Results of the regression analysis for Equation (1) by affiliated industries: Firms in other industries $\left(\mathrm{ENV} \_\mathrm{IND}=0\right) . M V_{i t}=\alpha_{0}+\alpha_{1} A S S E T_{i t}+\alpha_{2} L I A B_{i t}+$ $\alpha_{3} N I_{i t}+\sum \beta \times C E P_{i t}+\varepsilon_{i t}$.

\begin{tabular}{|c|c|c|c|c|c|c|c|c|c|c|c|c|}
\hline \multirow[b]{2}{*}{ ASSET } & \multicolumn{12}{|c|}{ Dependent Variable $=\mathrm{MV}$} \\
\hline & $\begin{array}{c}0.156^{* * *} \\
(5.227)\end{array}$ & $\begin{array}{c}0.155^{* * *} \\
(5.206)\end{array}$ & $\begin{array}{c}0.155^{* * *} \\
(5.156)\end{array}$ & $\begin{array}{c}0.156^{* * *} \\
(5.208)\end{array}$ & $\begin{array}{c}0.154 * * * \\
(5.101)\end{array}$ & $\begin{array}{c}0.127^{* * *} \\
(3.183)\end{array}$ & $\begin{array}{c}0.153^{* * *} \\
(4.978)\end{array}$ & $\begin{array}{c}0.153^{* * *} \\
(5.023)\end{array}$ & $\begin{array}{c}0.156^{* * *} \\
(5.235)\end{array}$ & $\begin{array}{c}0.156^{* * *} \\
(5.221)\end{array}$ & $\begin{array}{c}0.147^{* * *} \\
(4.520)\end{array}$ & $\begin{array}{c}0.152 * * * \\
(5.069)\end{array}$ \\
\hline LIAB & $\begin{array}{c}-0.044^{* * *} \\
(-0.798)\end{array}$ & $\begin{array}{c}-0.042^{* * *} \\
(-0.765)\end{array}$ & $\begin{array}{c}-0.042^{* * *} \\
(-0.752)\end{array}$ & $\begin{array}{c}-0.044^{* * *} \\
(-0.798)\end{array}$ & $\begin{array}{c}-0.044^{* * *} \\
(-0.801)\end{array}$ & $\begin{array}{c}-0.004^{* * *} \\
(-0.054)\end{array}$ & $\begin{array}{c}-0.043^{* * *} \\
(-0.781)\end{array}$ & $\begin{array}{c}-0.047^{* * *} \\
(-0.841)\end{array}$ & $\begin{array}{c}-0.047^{* * *} \\
(-0.850)\end{array}$ & $\begin{array}{c}-0.044^{* * *} \\
(-0.806)\end{array}$ & $\begin{array}{c}-0.036^{* * *} \\
(-0.643)\end{array}$ & $\begin{array}{c}-0.052^{* * * *} \\
(-0.943)\end{array}$ \\
\hline NI & $\begin{array}{c}3.666^{* * *} \\
(9.117)\end{array}$ & $\begin{array}{c}3.649 * * * \\
(9.047)\end{array}$ & $\begin{array}{c}3.672 * * * \\
(9.092)\end{array}$ & $\begin{array}{c}3.664 * * * \\
(9.071)\end{array}$ & $\begin{array}{c}3.649^{* * *} \\
(9.004)\end{array}$ & $\begin{array}{c}3.609 * * * \\
(8.907)\end{array}$ & $\begin{array}{c}3.663^{* * * *} \\
(9.082)\end{array}$ & $\begin{array}{c}3.676^{* * *} \\
(9.099)\end{array}$ & $\begin{array}{c}3.680 * * * \\
(9.150)\end{array}$ & $\begin{array}{c}3.655^{* * *} \\
(9.039)\end{array}$ & $\begin{array}{c}3.641 * * * \\
(9.003)\end{array}$ & $\begin{array}{c}3.699 * * * \\
(9.198)\end{array}$ \\
\hline POL1 & & $\begin{array}{c}0.510 \\
(0.739)\end{array}$ & & & & & & & & & & \\
\hline POL2 & & & $\begin{array}{c}-0.404 \\
(-0.316)\end{array}$ & & & & & & & & & \\
\hline PRO & & & & $\begin{array}{c}0.075 \\
(0.094)\end{array}$ & & & & & & & & \\
\hline GHG & & & & & $\begin{array}{c}0.054 \\
(0.416)\end{array}$ & & & & & & & \\
\hline ENERGY & & & & & & $\begin{array}{c}0.007 \\
(1.090)\end{array}$ & & & & & & \\
\hline WATER & & & & & & & $\begin{array}{c}0.009 \\
(0.405)\end{array}$ & & & & & \\
\hline WASTE & & & & & & & & $\begin{array}{c}0.001 \\
(0.418)\end{array}$ & & & & \\
\hline HAZ_WASTE & & & & & & & & & $\begin{array}{c}0.035 \\
(1.043)\end{array}$ & & & \\
\hline EMP & & & & & & & & & & $\begin{array}{c}0.457 \\
(0.377)\end{array}$ & & \\
\hline EOP1 & & & & & & & & & & & $\begin{array}{c}0.420 \\
(0.689)\end{array}$ & \\
\hline EOP2 & & & & & & & & & & & & $\begin{array}{c}0.629 \\
(1.247)\end{array}$ \\
\hline Constant & $\begin{array}{c}-3.883 \\
(-1.629)\end{array}$ & $\begin{array}{c}-3.919 \\
(-1.641)\end{array}$ & $\begin{array}{c}-3.538 \\
(-1.346)\end{array}$ & $\begin{array}{c}-3.936 \\
(-1.601)\end{array}$ & $\begin{array}{c}-3.835 \\
(-1.602)\end{array}$ & $\begin{array}{l}-4.343 * \\
(-1.795)\end{array}$ & $\begin{array}{c}-3.824 \\
(-1.596)\end{array}$ & $\begin{array}{c}-3.710 \\
(-1.529)\end{array}$ & $\begin{array}{c}-3.729 \\
(-1.562)\end{array}$ & $\begin{array}{l}-4.132 * \\
(-1.665)\end{array}$ & $\begin{array}{c}-3.642 \\
(-1.509)\end{array}$ & $\begin{array}{c}-3.124 \\
(-1.272)\end{array}$ \\
\hline Observations & 167 & 167 & 167 & 167 & 167 & 167 & 167 & 167 & 167 & 167 & 167 & 167 \\
\hline Adjusted R-squared & 0.817 & 0.817 & 0.817 & 0.817 & 0.817 & 0.818 & 0.817 & 0.817 & 0.818 & 0.817 & 0.817 & 0.818 \\
\hline
\end{tabular}


Here again, we find multicollinearity problems in Table 7. VIFs exceed 10 for POL1, GHG, and WASTE in the fourth, fifth, and ninth columns, respectively. Similar to the results in Table 6, the VIFs are often higher in the regression results with individual EPI variables. Variance inflation factors (VIFs) range from 4.66 to 14.81 . However, column 12 of Table 7 shows that the VIFs of EMP, EOP1, and EOP2 are 1.57, 5.54, and 2.83, respectively, much lower than those of EPI variables. Overall, our results indicate that environmental information provides additional value relevance only for investors in firms from environmentally sensitive industries.

\section{Additional Tests}

Easton and Sommers [41] warned that the results of empirical analyses using the Ohlson model can be affected by the "scale effect", which occurs when a small number of the largest firms drive the results of the entire regression. Prior studies point out that the scale effect results in model inefficiency, causing heteroscedasticity and biases in the regression coefficients [34,42]. To deal with the scale effect, Barth and Kallapur [42] proposed the inclusion of a scale proxy to alleviate coefficient bias. Recently, Gil-Alana et al. [43] suggested using an exogenous variable (e.g., number of employees) as the deflator, since traditional deflators cause endogeneity problems.

We perform additional tests to address these robustness issues. First, we scale the variables in the regression models by the number of common shares outstanding. Firm dummies are also included to control for unobserved, firm-specific fixed effects. Table 9 presents the results of the scaled regression model, which includes firms in environmentally sensitive industries only. Consistent with the results of the main analysis, we find that some of the individual EPI variables-POL1, GHG, WATER, and WASTE - and two out of three EPCs-EOP1 and EOP2-have additional value relevance. We also find a multicollinearity problem (VIFs exceeding 10) for GHG and WATER in the seventh column.

Second, we assess the value relevance of CEP as follows:

$$
M V_{i t}=\alpha_{0}+\alpha_{1} B V_{i t}+\alpha_{2} N I_{i t}+\sum \beta \times C E P_{i t}+\varepsilon_{i t}
$$

where $B V_{i t}$ is the book value of common equity. We scale all variables in Equation (2) by the number of outstanding shares of common stocks. Our (untabulated) results with respect to the association between $E P I_{i t}\left(E P C_{i t}\right)$ and $M V_{i t}$ remain unchanged.

We conduct two additional approaches to address the endogeneity issue. First, we report the results based on the instrumental variables approach in Table 10. The chosen instrumental variable is $E P C_{i t-1}$, which is highly correlated with $E P C_{i t}$, but is uncorrelated with $M V_{i t}$, the dependent variable in the second stage. In these regressions, we only include firms with non-missing values for each category of EPCs to focus on the pure impact of environmental performance on firm value. The results indicate that while the coefficients on EMP and EOP1 are significantly positive at the $5 \%$ level, the coefficient on EOP2 is non-significant. The results also indicate that environmental performance related to environmental management and environmental operations in terms of energy, water, and greenhouse gas improves firm value more than environmental performance in terms of waste and hazardous waste management. 
Table 9. Results of the scaled model test: Firms in environmentally-sensitive industries (ENV_IND = 1).

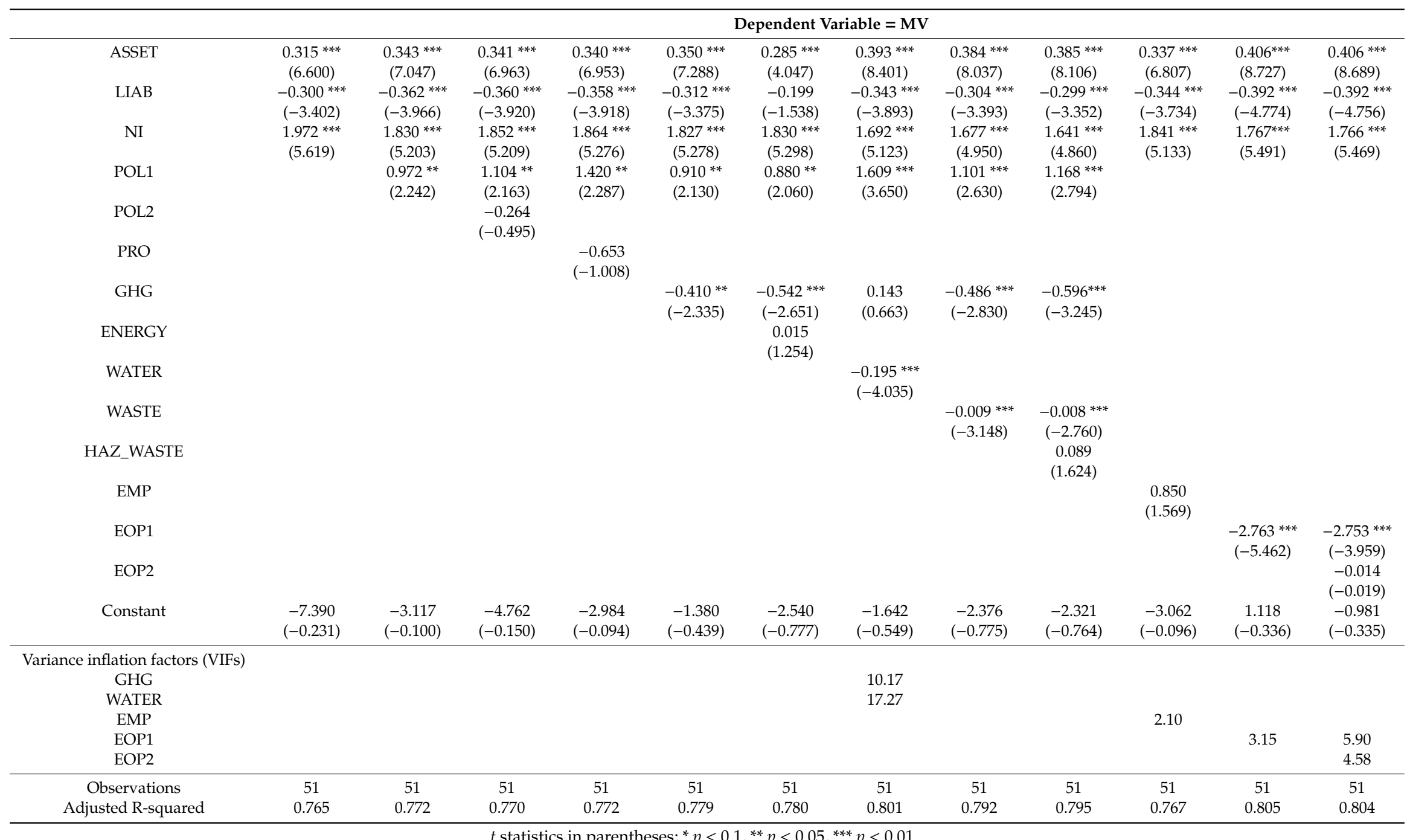


Table 10. Results of the regression models based on the instrumental variable method.

\begin{tabular}{|c|c|c|c|}
\hline Variables & MV & MV & MV \\
\hline EMP & $\begin{array}{l}3.820 * * \\
(2.292)\end{array}$ & $\begin{array}{l}3.764^{* *} \\
(2.362)\end{array}$ & $\begin{array}{l}3.774^{* *} \\
(2.354)\end{array}$ \\
\hline EOP1 & & $\begin{array}{c}1.889 * * * \\
(3.507)\end{array}$ & $\begin{array}{c}1.932 * * * \\
(2.667)\end{array}$ \\
\hline EOP2 & & & $\begin{array}{l}-0.082 \\
(-0.096)\end{array}$ \\
\hline ASSET & $\begin{array}{c}0.120^{* * *} \\
(3.941)\end{array}$ & $\begin{array}{c}0.088^{* * *} \\
(2.889)\end{array}$ & $\begin{array}{c}0.088^{* * * *} \\
(2.844)\end{array}$ \\
\hline LIAB & $\begin{array}{c}0.081 \\
(1.334)\end{array}$ & $\begin{array}{l}0.107^{*} \\
(1.835)\end{array}$ & $\begin{array}{l}0.109 * \\
(1.767)\end{array}$ \\
\hline NI & $\begin{array}{c}3.548^{* * *} \\
(8.520)\end{array}$ & $\begin{array}{c}3.276 * * * \\
(8.115)\end{array}$ & $\begin{array}{c}3.269 * * * \\
(7.938)\end{array}$ \\
\hline Constant & $\begin{array}{c}-8.183^{* * *} \\
(-2.862)\end{array}$ & $\begin{array}{l}-6.781 * * \\
(-2.440)\end{array}$ & $\begin{array}{l}-6.854^{* *} \\
(-2.367)\end{array}$ \\
\hline Observations & 160 & 160 & 160 \\
\hline Adjusted R-squared & 0.911 & 0.918 & 0.918 \\
\hline
\end{tabular}

Second, we report the results based on the Granger causality approach [44]. Using lagged values of the dependent variables, Granger causality tests examine whether independent variables provide more information compared to the information provided by the lagged values of the dependent variables. Although the Granger causality test cannot clarify the causality between independent variables and dependent variables in a perfect way, it can be used to identify whether time series of independent variables are useful in predicting those of dependent variables, i.e., the "Granger cause".

Granger causality tests are used to distinguish between association and causality in social science research. For instance, Dowell et al. [45] make use of Granger causality tests in examining the association between the value of a firm and environmental standards of a firm. Their results show that a firm's environmental standards do not have a significant ability to predict the value of the firm, which implies that the causality between a firm's environmental standards and its value is inconclusive. We address the causality between CEP and market value using the following equations using the Granger causality approach:

$$
\begin{aligned}
& M V_{i t}=\alpha_{0}+\alpha_{1} M V_{i t-1}+\alpha_{2} E P C_{i t-1}+\alpha_{3} A_{S S E T_{i t}}+\alpha_{4} L I A B_{i t}+\alpha_{5} N I_{i t}+\varepsilon_{i t} \\
& E P C_{i t}=\alpha_{0}+\alpha_{1} E P C_{i t-1}+\alpha_{2} M V_{i t-1}+\alpha_{3} A_{S S E T_{i t}}+\alpha_{4} L I A B_{i t}+\alpha_{5} N I_{i t}+\varepsilon_{i t}
\end{aligned}
$$

where $M V_{i t-1}$ and $E P C_{i t-1}$ represent the $M V$ and $E P C$ in year $t-1$ for firm $i$.

In addition, we include two lags of the explanatory variables to address autocorrelation among variables as follows:

$$
\begin{aligned}
& M V_{i t}=\alpha_{0}+\alpha_{1} M V_{i t-1}+\alpha_{2} M V_{i t-2}+\alpha_{3} E P C_{i t-1}+\alpha_{4} E P C_{i t-2}+\alpha_{5} A S S E T_{i t}+\alpha_{6} L I A B_{i t}+\alpha_{7} N_{i t}+\varepsilon_{i t} \\
& E P C_{i t}=\alpha_{0}+\alpha_{1} E P C_{i t-1}+\alpha_{2} E P C_{i t-2}+\alpha_{3} M V_{i t-1}+\alpha_{4} M V_{i t-2}+\alpha_{5} A S S E T_{i t}+\alpha_{6} L I A B_{i t}+\alpha_{7} N_{i t}+\varepsilon_{i t}
\end{aligned}
$$

Tables 11 and 12 present the results of the regression models testing "Granger causality" between the CEP measures and firm market values. Table 11 provides the estimates of Equations (3) and (4), respectively. We find a significant positive relationship between EOP1, one of the three CEP measures, in year $t-1$ and market value in year $t(p=2.174)$. However, the relationship between the market value in year $t$ and the other CEP measures in year $t-1$ are not statistically significant. Accordingly, CEP does not "Granger cause" market value in a consistent way. As for Equation (4), the relationships between CEP measures in year $t$ and market value in year $t-1$ are not statistically significant. Table 12 provides the regression results of Equations (5) and (6), respectively. The results are qualitatively similar to those of Table 11. 
Table 11. Results of the regression models testing Granger causality: Including one lag of the explanatory variables.

\begin{tabular}{|c|c|c|c|c|c|c|}
\hline Equation & & (3) & & & (4) & \\
\hline Dependent Variable & MV & MV & MV & EMP & EOP1 & EOP2 \\
\hline $\operatorname{MV}(t-1)$ & $\begin{array}{c}0.491 * * * \\
(8.053)\end{array}$ & $\begin{array}{c}0.465^{* * *} \\
(7.817)\end{array}$ & $\begin{array}{c}0.497 * * * \\
(8.492)\end{array}$ & $\begin{array}{c}0.001 \\
(0.320)\end{array}$ & $\begin{array}{c}0.009 \\
(0.379)\end{array}$ & $\begin{array}{c}0.007 \\
(0.805)\end{array}$ \\
\hline $\operatorname{EMP}(t-1)$ & $\begin{array}{c}0.220 \\
(0.219)\end{array}$ & & & $\begin{array}{l}0.646^{* * *} \\
(12.550)\end{array}$ & & \\
\hline $\mathrm{EOP} 1(t-1)$ & & $\begin{array}{c}0.605 \\
(1.174)\end{array}$ & & & $\begin{array}{l}0.922 * * * \\
(29.305)\end{array}$ & \\
\hline $\mathrm{EOP} 2(t-1)$ & & & $\begin{array}{c}0.707 \\
(1.535)\end{array}$ & & & $\begin{array}{c}0.703 \text { *** } \\
(10.807)\end{array}$ \\
\hline ASSET & $\begin{array}{c}0.031 \\
(1.080)\end{array}$ & $\begin{array}{c}0.012 \\
(0.407)\end{array}$ & $\begin{array}{c}0.023 \\
(0.774)\end{array}$ & $\begin{array}{c}0.000 \\
(0.120)\end{array}$ & $\begin{array}{c}-0.004^{* *} \\
(-2.349)\end{array}$ & $\begin{array}{c}-0.006 \\
(-1.414)\end{array}$ \\
\hline LIAB & $\begin{array}{c}0.058 \\
(1.023)\end{array}$ & $\begin{array}{c}0.079 \\
(1.407)\end{array}$ & $\begin{array}{c}0.057 \\
(1.028)\end{array}$ & $\begin{array}{c}-0.002 \\
(-0.694)\end{array}$ & $\begin{array}{c}0.003 \\
(0.808)\end{array}$ & $\begin{array}{l}0.016^{* * *} \\
(1.978)\end{array}$ \\
\hline NI & $\begin{array}{c}2.473 * * * \\
(6.272)\end{array}$ & $\begin{array}{c}2.480 * * * \\
(6.420)\end{array}$ & $\begin{array}{c}2.490 * * * \\
(6.386)\end{array}$ & $\begin{array}{c}0.009 \\
(0.428)\end{array}$ & $\begin{array}{l}0.051^{* *} \\
(2.077)\end{array}$ & $\begin{array}{c}0.020 \\
(0.363)\end{array}$ \\
\hline Constant & $\begin{array}{l}-2.652 \\
(-1.057)\end{array}$ & $\begin{array}{l}-1.877 \\
(-0.790)\end{array}$ & $\begin{array}{l}-1.876 \\
(-0.777)\end{array}$ & $\begin{array}{c}0.292 * * \\
(2.270)\end{array}$ & $\begin{array}{c}-0.010 \\
(-0.066)\end{array}$ & $\begin{array}{c}-0.462 \\
(-1.355)\end{array}$ \\
\hline Observations & 160 & 160 & 160 & 160 & 160 & 160 \\
\hline Adjusted R-squared & 0.937 & 0.940 & 0.939 & 0.685 & 0.961 & 0.743 \\
\hline
\end{tabular}

$t$ statistics in parentheses; ${ }^{*} p<0.1,{ }^{* *} p<0.05,{ }^{* * *} p<0.01$.

Table 12. Results of the regression models testing Granger causality: Including two lags of the explanatory variables.

\begin{tabular}{|c|c|c|c|c|c|c|}
\hline Equation & & (5) & & & (6) & \\
\hline Dependent Variable & MV & MV & MV & EMP & EOP1 & EOP2 \\
\hline $\mathrm{MV}(t-1)$ & $\begin{array}{c}0.538^{* * *} \\
(5.673)\end{array}$ & $\begin{array}{c}0.511^{* * *} \\
(5.360)\end{array}$ & $\begin{array}{c}0.527^{* * *} \\
(5.735)\end{array}$ & $\begin{array}{c}-0.002 \\
(-0.642)\end{array}$ & $\begin{array}{c}0.002 \\
(0.544)\end{array}$ & $\begin{array}{c}0.003 \\
(0.173)\end{array}$ \\
\hline $\operatorname{MV}(t-2)$ & $\begin{array}{c}0.101 \\
(1.335)\end{array}$ & $\begin{array}{c}0.108 \\
(1.480)\end{array}$ & $\begin{array}{l}0.126^{*} \\
(1.771)\end{array}$ & $\begin{array}{c}-0.002 \\
(-0.569)\end{array}$ & $\begin{array}{c}0.002 \\
(0.537)\end{array}$ & $\begin{array}{c}0.011 \\
(0.825)\end{array}$ \\
\hline $\operatorname{EMP}(t-1)$ & $\begin{array}{c}0.980 \\
(0.533)\end{array}$ & & & $\begin{array}{c}0.474^{* * *} \\
(6.772)\end{array}$ & & \\
\hline $\operatorname{EMP}(t-2)$ & $\begin{array}{c}0.212 \\
(0.135)\end{array}$ & & & $\begin{array}{c}0.003 \\
(0.046)\end{array}$ & & \\
\hline $\mathrm{EOP} 1(t-1)$ & & $\begin{array}{c}0.313 \\
(0.226)\end{array}$ & & & $\begin{array}{l}0.921^{* * *} \\
(14.296)\end{array}$ & \\
\hline $\mathrm{EOP} 1(t-2)$ & & $\begin{array}{c}0.603 \\
(0.451)\end{array}$ & & & $\begin{array}{c}0.099 \\
(1.592)\end{array}$ & \\
\hline $\mathrm{EOP} 2(t-1)$ & & & $\begin{array}{c}0.708 \\
(0.935)\end{array}$ & & & $\begin{array}{r}0.796^{* * *} \\
(5.867)\end{array}$ \\
\hline $\mathrm{EOP} 2(t-2)$ & & & $\begin{array}{c}0.752 \\
(0.997)\end{array}$ & & & $\begin{array}{c}-0.091 \\
(-0.670)\end{array}$ \\
\hline ASSET & $\begin{array}{c}0.043 \\
(1.390)\end{array}$ & $\begin{array}{c}0.025 \\
(0.735)\end{array}$ & $\begin{array}{c}0.028 \\
(0.929)\end{array}$ & $\begin{array}{c}0.002 \\
(1.317)\end{array}$ & $\begin{array}{l}-0.004^{* *} \\
(-2.403)\end{array}$ & $\begin{array}{c}-0.007 \\
(-1.316)\end{array}$ \\
\hline LIAB & $\begin{array}{c}0.022 \\
(0.379)\end{array}$ & $\begin{array}{c}0.046 \\
(0.754)\end{array}$ & $\begin{array}{c}0.021 \\
(0.378)\end{array}$ & $\begin{array}{c}-0.003 \\
(-1.461)\end{array}$ & $\begin{array}{c}0.004 \\
(1.263)\end{array}$ & $\begin{array}{c}0.015 \\
(1.490)\end{array}$ \\
\hline NI & $\begin{array}{l}1.149 * * \\
(2.375)\end{array}$ & $\begin{array}{l}1.194 * * \\
(2.493)\end{array}$ & $\begin{array}{l}1.119^{* *} \\
(2.358)\end{array}$ & $\begin{array}{c}0.014 \\
(0.770)\end{array}$ & $\begin{array}{c}0.016 \\
(0.726)\end{array}$ & $\begin{array}{c}0.021 \\
(0.244)\end{array}$ \\
\hline Constant & $\begin{array}{c}-2.493 \\
(-0.796)\end{array}$ & $\begin{array}{c}-1.251 \\
(-0.428)\end{array}$ & $\begin{array}{c}-0.442 \\
(-0.155)\end{array}$ & $\begin{array}{c}0.408^{* * *} \\
(3.421)\end{array}$ & $\begin{array}{c}0.017 \\
(0.128)\end{array}$ & $\begin{array}{c}-0.415 \\
(-0.811)\end{array}$ \\
\hline Observations & 107 & 107 & 107 & 107 & 107 & 107 \\
\hline Adjusted R-squared & 0.952 & 0.953 & 0.956 & 0.772 & 0.985 & 0.720 \\
\hline
\end{tabular}




\section{Conclusions}

Corporate environmental performance, despite its increasing importance, is elusive and difficult to define without debate. Prior studies examine the value relevance of environmental information using various measures, which are very different from one another. The use of different proxies for environmental information can be misleading and/or confusing, hindering derivation and preventing a general conclusion in terms of firm value relevance. To our knowledge, this is the first study to examine the additional value relevance of multidimensional EPCs using the modified version of the Ohlson model [12]. Using environmental performance data from the ASSET4 database spanning 2009 to 2013, we find that capital markets reflect environmental performance information in firm valuations in Korea.

We find additional value relevance for some EPI variables, POL1 (energy efficiency policy), PRO (environmental process), and GHG (emissions of $\mathrm{CO}_{2}$ and $\mathrm{CO}_{2}$ equivalents). These EPIs show significant and positive associations with firm value in addition to positive economic significance. With regard to EPCs, EMP and EOP1 have significant and positive impacts on firm market value. This result supports the first hypothesis to some degree. It is worthwhile to note that adding some EPIs, such as POL2 (water efficiency), ENERGY (direct and indirect energy consumption), and WASTE (amount of waste produced) cause multicollinearity problems, indicated by high VIFs. In the results of the empirical analysis using EPCs instead of EPIs, considering collinearity among EPIs, we find that two out of three EPCs are associated with firm market value. Our results are consistent with those of prior research, implying that environmental performance cannot be interpreted by a fixed set of indicators, but that two dimensions considering the multidimensional nature of environmental information may be suitable for analyzing it properly. We further examine the value relevance of environmental performance by analyzing subsamples of affiliated industries of the firms in the sample. The results show that environmental performance information is value relevant only for firms from "environmentally sensitive" industries, including the chemical, oil, mining, metal, paper, and pulp industries. This finding is consistent with those of prior studies that emphasize the role of affiliated industries in the presentation of environmental information content.

This study has several implications. First, it adds empirical evidence with regard to the value relevance of corporate environmental performance. Additionally, this paper focuses on Korea, where stakeholders' recognition of corporate social responsibility has increased steadily in recent years. Our results show that corporations' efforts to improve their environmental performance have been beneficial for market participants in Korea, as was shown in prior studies focusing on the U.S. or E.U. capital markets. Second, investors who understand the multidimensional nature of environmental performance are more likely to make optimal investment decisions. By focusing on comprehensive environmental performance constructs derived from EPIs, such as the standardized sum of energy usage, water usage, and greenhouse gas emissions, investors can track the real impact of environmental performance on firm value. Failure to do so may lead investors to make suboptimal investment decisions. Finally, this study also has important implications for researchers who work with environmental metrics. The results of this empirical study suggest that simply putting different EPIs into valuation models without establishing multidimensional constructs may lead to improper assessment of environmental performance. Evaluating environmental performance using a single index may also be a misrepresentation of the dimensions of this construct.

Despite these contributions, there are a few limitations. First, our results are limited to the Korean context. It may be difficult to generalize the findings of this study to other countries due to differences in legal systems, which may also affect the value relevance of CEP. It may be beneficial for future researchers to examine cross-country comparisons or the relationships between legal systems and the value relevance of CEP. Second, the sample firms were not required to have their environmental performance data verified by a government agency. They voluntarily disclosed their environmental performance data without any assurances of its validity. Future research can address issues regarding 
the validity of environmental information. Future researchers could also examine the association between the validity of environmental information and firm value.

Author Contributions: Conceptualization, H.C.; methodology, H.C.; formal analysis, H.C.; writing-original draft preparation, H.C.; writing—review and editing, H.C. and J.L.; supervision, I.H. All authors have read and agreed to the published version of the manuscript.

Funding: This research received no external funding.

Conflicts of Interest: The authors declare no conflict of interest.

\section{Abbreviations}

$\begin{array}{ll}\text { CEP } & \text { Corporate Environmental Performance } \\ \text { EPI } & \text { Environmental Performance Indicator } \\ \text { EPC } & \text { Environmental Performance Construct } \\ \text { EMP } & \text { Environmental Management Performance } \\ \text { EOP } & \text { Environmental Operational Performance } \\ \text { PCA } & \text { Principal Component Analysis } \\ \text { EFA } & \text { Exploratory Factor Analysis }\end{array}$

\section{Appendix A Data Source of ASSET4 Database}

According to Thomson Reuters, ASSET4 strictly sources publicly available information, including sustainability/CSR reports, company websites, annual reports, proxy filings, non-governmental organizations (NGOs) as well as news of all major providers. In addition to this, $\mathrm{CO}_{2}$ data is sourced from the Carbon Disclosure Project. The ASSET4 database rate companies against over 750 individual data points, which are combined into over 250 key performance indicators (KPIs). These KPI scores are grouped within 4 categories: Economic Performance, Environmental Performance, Social Performance, and Corporate Governance Performance.

\section{References}

1. Dixon-Fowler, H.R.; Slater, D.J.; Johnson, J.L.; Ellstrand, A.E.; Romi, A.M. Beyond “does it pay to be green?" A meta-analysis of moderators of the CEP-CFP relationship. J. Bus. Ethics 2013, 112, 353-3366. [CrossRef]

2. Barth, M.E.; McNichols, M.F. Estimation and market valuation of environmental liabilities relating to superfund sites. J. Account. Res. 1994, 32, 177-209. [CrossRef]

3. Cormier, D.; Magnan, M. Investors' assessment of implicit environmental liabilities: An empirical investigation. J. Account. Public Policy 1997, 16, 215-241. [CrossRef]

4. Matsumura, E.M.; Prakash, R. Firm-Value Effects of Carbon Emissions and Carbon Disclosures. Account. Rev. 2014, 89, 695-724. [CrossRef]

5. Hughes, K. The value relevance of nonfinancial measures of air pollution in the electric utility industry. Account. Rev. 2000, 75, 209-228. [CrossRef]

6. McWilliams, A.; Siegel, D. Corporate social responsibility and financial performance: Correlation or misspecification? Strateg. Manag. J. 2000, 21, 603-609. [CrossRef]

7. Etzion, D. Research on organizations and the natural environment, 1992-present: A review. J. Manag. 2007, 33, 637-664. [CrossRef]

8. Xie, S.; Hayase, K. Corporate environmental performance evaluation: A measurement model and a new concept. Bus. Strategye Environ. 2007, 16, 148-168. [CrossRef]

9. Rahman, N.; Post, C. Measurement issues in environmental corporate social responsibility (ECSR): Toward a transparent, reliable, and construct valid instrument. J. Bus. Ethics 2012, 105, 307-319. [CrossRef]

10. Fabrigar, L.R.; Wegener, D.T.; MacCallum, R.C.; Strahan, E.J. Evaluating the use of exploratory factor analysis in psychological research. Psychol. Methods 1999, 4, 272. [CrossRef]

11. Trumpp, C.; Endrikat, J.; Zopf, C.; Guenther, E. Definition, conceptualization, and measurement of corporate environmental performance: A critical examination of a multidimensional construct. J. Bus. Ethics 2015, 126, 185-204. [CrossRef]

12. Ohlson, J.A. Earnings, book values, and dividends in equity valuation. Contemp. Account. Res. 1995, 11, 661-687. [CrossRef] 
13. Wong, C.S.; Law, K.S.; Huang, G.H. On the importance of conducting construct-level analysis for multidimensional constructs in theory development and testing. J. Manag. 2008, 34, 744-764. [CrossRef]

14. Connors, E.; Johnston, H.H.; Gao, L.S. The informational value of Toxics Release Inventory performance. Sustain. Account. Manag. Policy J. 2013, 4, 32-55. [CrossRef]

15. Clarkson, P.M.; Li, Y.; Richardson, G.D. The market valuation of environmental capital expenditures by pulp and paper companies. Account. Rev. 2004, 79, 329-353. [CrossRef]

16. Hart, S.L.; Ahuja, G. Does it pay to be green? An empirical examination of the relationship between emission reduction and firm performance. Bus. Strategy Environ. 1996, 5, 30-37. [CrossRef]

17. Johnston, D.M.; Sefcik, S.E.; Soderstrom, N.S. The value relevance of greenhouse gas emissions allowances: An exploratory study in the related United States $\mathrm{SO}_{2}$ market. Eur. Account. Rev. 2008, 17, 747-764. [CrossRef]

18. Konar, S.; Cohen, M.A. Information as regulation: The effect of community right to know laws on toxic emissions. J. Environ. Econ. Manag. 1997, 32, 109-124. [CrossRef]

19. Chapple, L.; Clarkson, P.M.; Gold, D.L. The cost of carbon: Capital market effects of the proposed emission trading scheme (ETS). Abacus 2013, 49, 1-33. [CrossRef]

20. Jo, H.; Kim, H.; Park, K. Corporate environmental responsibility and firm performance in the financial services sector. J. Bus. Ethics 2015, 131, 257-284. [CrossRef]

21. Kim, H.; Park, K.; Ryu, D. Corporate Environmental Responsibility: A Legal Origins Perspective. J. Bus. Ethics 2017, 140, 381-402. [CrossRef]

22. Miralles-Quirós, M.; Miralles-Quirós, J.; Gonçalves, L. The value relevance of environmental, social, and governance performance: The Brazilian Case. Sustainability 2018, 10, 574. [CrossRef]

23. Jiang, C.; Fu, Q. A Win-Win Outcome between Corporate Environmental Performance and Corporate Value: From the Perspective of Stakeholders. Sustainability 2019, 11, 921. [CrossRef]

24. Sutopo, B.; Kot, S.; Adiati, A.; Ardila, L. Sustainability Reporting and Value Relevance of Financial Statements. Sustainability 2018, 10, 678. [CrossRef]

25. Hunter, J.E.; Schmidt, F.L. Methods of Meta-Analysis: Correcting Error and Bias in Research Findings; Sage: London, UK, 2004; p. 672.

26. Edwards, J.R. Construct validation in organizational behavior research. In Organizational Behavior: A Management Challenge; Psychology Press: Hove, UK, 2003; p. 311.

27. International Organization for Standardization. ISO 14031: 2013. Environmental Performance Evaluation-Guidelines; ISO: Geneva, Switzerland, 2013.

28. Clemens, B.; Bakstran, L.; Hamakawa, C. Reliable categories of environmental policies. Int. J. Sustain. Strateg. Manag. 2010, 2, 234-255. [CrossRef]

29. Law, K.S.; Wong, C.S.; Mobley, W.M. Toward a taxonomy of multidimensional constructs. Acad. Manag. Rev. 1998, 23, 741-755. [CrossRef]

30. Government of the Republic of Korea, Ministry of Environment. The Revised Plan of the National Roadmap for Greenhouse Gas Reductions by 2030 and the Plan for the National Greenhouse Gas Emission Permit Allocation from 2018 to 2020 are Finalized. Available online: http://eng.me.go.kr/eng/web/board/read.do?pagerOffset=10\&maxPageItems=10\&maxIndexPages=10\& searchKey=titleOrContent\&searchValue $=$ greenhouse + gas $+\&$ menuId $=461 \&$ orgCd $=\&$ boardId $=903080 \&$ boardMasterId=522\&boardCategoryId=\&decorator=\&firstItemIndex= (accessed on 21 August 2020).

31. Gray, R.; Kouhy, R.; Lavers, S. Corporate social and environmental reporting: A review of the literature and a longitudinal study of UK disclosure. Account. Audit. Account. J. 1995, 8, 47-77. [CrossRef]

32. Cho, C.H.; Patten, D.M. The role of environmental disclosures as tools of legitimacy: A research note. Account. Organ. Soc. 2007, 32, 639-647. [CrossRef]

33. Reverte, C. Corporate social responsibility disclosure and market valuation: Evidence from Spanish listed firms. Rev. Manag. Sci. 2016, 10, 411-435. [CrossRef]

34. Barth, M.E.; Clinch, G. Scale effects in capital markets-based accounting research. J. Bus. Financ. Account. 2009, 36, 253-288. [CrossRef]

35. Ziliak, S.T.; McCloskey, D.N. Size matters: The standard error of regressions in the American Economic Review. J. Socio Econ. 2004, 33, 527-546. [CrossRef]

36. Ziegler, A.; Busch, T.; Hoffmann, V.H. Disclosed corporate responses to climate change and stock performance: An international empirical analysis. Energy Econ. 2011, 33, 1283-1294. [CrossRef] 
37. Larcker, D.F.; Richardson, S.A.; Tuna, I. Corporate governance, accounting outcomes, and organizational performance. Account. Rev. 2007, 82, 963-1008. [CrossRef]

38. Trumpp, C.; Guenther, T. Too little or too much? Exploring U-shaped relationships between corporate environmental performance and corporate financial performance. Bus. Strategy Environ. 2017, 26, 49-68. [CrossRef]

39. Lennox, C.S.; Francis, J.R.; Wang, Z. Selection models in accounting research. Account. Rev. 2011, 87, 589-616. [CrossRef]

40. Song, M.K.; Lin, F.C.; Ward, S.E.; Fine, J.P. Composite variables: When and how. Nurs. Res. 2013, 62, 45-49. [CrossRef]

41. Easton, P.D.; Sommers, G.A. Scale and the Scale Effect in Market-based Accounting Research. J. Bus. Financ. Account. 2003, 30, 25-56. [CrossRef]

42. Barth, M.E.; Kallapur, S. The Effects of Cross-Sectional Scale Differences on Regression Results in Empirical Accounting Research. Contemp. Account. Res. 1996, 13, 527-567. [CrossRef]

43. Gil-Alana, L.A.; Iniguez-Sanchez, R.; López-Espinosa, G. Endogenous problems in cross-sectional valuation models based on accounting information. Rev. Quant. Financ. Account. 2011, 37, 245-265. [CrossRef]

44. Granger, C.W. Investigating causal relations by econometric models and cross-spectral methods. Econom. J. Econom. Soc. 1969, 424-438. [CrossRef]

45. Dowell, G.; Hart, S.; Yeung, B. Do corporate global environmental standards create or destroy market value? Manag. Sci. 2000, 46, 1059-1074. [CrossRef]

(C) 2020 by the authors. Licensee MDPI, Basel, Switzerland. This article is an open access article distributed under the terms and conditions of the Creative Commons Attribution (CC BY) license (http://creativecommons.org/licenses/by/4.0/). 